\title{
Cylinder Dosing Unit
}

National Cancer Institute

\section{Source}

National Cancer Institute. Cylinder Dosing Unit. NCI Thesaurus. Code C48489.

A dosing unit equal to the amount of active ing redient(s) contained in a cylinder. 